\section{Band 27, Heft 5, Oktober 2011}

\section{Editorial}

348 Bedeutung von Zertifizierung und Zentrenbildung für die Viszeralmedizin

Post, S. (Mannheim); Betzler, M. (Essen)

Hauptthema

350 Zertifizierung und Zentrenbildung aus der Sicht der Deutschen Gesellschaft für Allgemein- und Viszeralchirurgie (DGAV)

Jost, J.O. (Berlin)

361 Bedeutung von Zertifizierung und Zentrenbildung in der Viszeralmedizin

Schepp, W.; Heitland, W. (München)

367 Erfahrungen mit einem Enddarmzentrum

Kirsch, J.; Herold, A. (Mannheim)

371 Erfahrungen in der Entwicklung zum zertifizierten minimal invasiven Zentrum

Pistorius, G.A. (Bamberg)

377 Sind Zentren für hepato-pankreatiko-biliäre

Erkrankungen sinnvoll?

Seehofer, D.; Neuhaus, P. (Berlin)

Interdisziplinäres Gespräch

387 Bedeutung von Zertifizierung und Zentrenbildung für die Viszeralmedizin

Bruch, H.-P.; Fellermann, K. (Lübeck) (Gesprächsleiter)

Originalarbeiten

391 Erfahrungen mit der Behandlung blutender Pseudoaneurismen bei komplizierter Pankreatitis Sileikis, A.; Beisa, V.; Rutkauskaite, D.; Misonis, N.; Strupas, K. (Vilnius)

\section{Vol. 27, Issue 5, October 2011}

\section{Editorial}

348 Relevance of Certification and Center Formation in Gastrointestinal Medicine and Surgery

Post, S. (Mannheim); Betzler, M. (Essen)

Main Topic

350 Certification and Center Formation from the Point of View of the German Society for General and Visceral Surgery (DGAV) Jost, J.O. (Berlin)

361 Certified Centers in Gastrointestinal Medicine and Surgery: Impact on Clinical Outcome Schepp, W.; Heitland, W. (München)

367 Experiences with a Center Specialized in Coloproctology

Kirsch, J.; Herold, A. (Mannheim)

371 Experiences in the Development into a Certified Minimally Invasive Surgical Center Pistorius, G.A. (Bamberg)

377 Are Specialized Centres for Hepato-PancreatoBiliary Diseases Useful? Seehofer, D.; Neuhaus, P. (Berlin)

Interdisciplinary Discussion

387 Relevance of Certification and Center Formation in Gastrointestinal Medicine and Surgery Bruch, H.-P.; Fellermann, K. (Lübeck) (Discussion Leader)

Original Articles

391 Management of Bleeding Pseudoaneurysms in Complicated Pancreatitis

Sileikis, A.; Beisa, V.; Rutkauskaite, D.; Misonis, N.; Strupas, K. (Vilnius)

\section{KARGER}

Fax +497614520714

Information@Karger.de

www.karger.com (c) 2011 S. Karger GmbH, Freiburg 


\section{Band 27, Heft 5, Oktober 2011}

397 Outcome der hepatisch intraarteriellen Chemotherapie bei Patienten mit nicht resektablen Lebermetastasen

Goi, T.; Sawai, K.; Koneri, K.; Katayama, K.; Yamaguchi, A. (Fukui)

403 News / Ticker

406 Tagungen und Kongresse

343 Impressum
Vol. 27, Issue 5, October 2011

397 Results of Hepatic Arterial Infusion Chemotherapy in Patients with Unresectable Liver Metastases Goi, T.; Sawai, K.; Koneri, K.; Katayama, K.; Yamaguchi, A. (Fukui)

403 News / Ticker

406 Meetings and Conferences

343 Imprint

\section{KARGER}

(C) 2011 S. Karger GmbH, Freiburg

Fax +497614520714 